\title{
Positive parenting, not physical punishment
}

\author{
John Fletcher MB BChir MPH
}

See related analysis article by Durrant and Ensom on page 1373 and at www.cmaj.ca/lookup/doi/10.1503/cmaj.101314

$\mathrm{I}$ s spanking wrong? Clearly, hitting anyone in anger or when losing an argument is bad behaviour. To do this to children sets a bad example and may only teach them that violence is a means to getting their own way. But what about a slap as the ultimate sanction and a means of enforcing boundaries and discipline? It's an obvious question and one in which parents will be interested. Are those who use physical punishment bad parents?

If they are, then they are in the company of roughly $90 \%$ of my parents' generation, ${ }^{1}$ including $70 \%$ of family doctors and $60 \%$ of pediatricians, who thought spanking acceptable in some circumstances. ${ }^{2}$ The proportion of parents who spank toddlers now is still high but closer to 50\%. ${ }^{3}$ Many parents will say that a good smack taught them right and wrong and that there is a role for it in teaching good behaviour.

Opponents of physical punishment will call upon a child's right to be protected from physical assault. Some argue that physical punishment is inescapably a form of violence, that spanking should be classified as a crime in itself and that parents should be prosecuted for punishing in this way.

So heated is this debate, and so long-running, that the question of whether spanking is morally "right or wrong" is probably intractable. A more promising line of enquiry, however, is whether the physical punishment of children is effective.

In a related article, Durrant and Ensom ${ }^{4}$ summarize research done over the last 20 years suggesting that the physical punishment of children is associated with increased levels of child aggression and is no better at eliciting compliance than other methods. Furthermore, physical punishment during childhood is associated with behavioural problems in adult life, including depression, unhappiness, anxiety, feelings of hopelessness, use of drugs and alcohol, and general psychological maladjustment. Their article may appear slanted toward a particular view, but that is likely because more evidence exists to support this view than to suggest that physical punishment is beneficial.

Supporters of spanking may argue that it is a question of degree and that spanking is beneficial unless practised to excess. This is possible, but it has always struck me that people using this line of reasoning in the face of clear evidence of harm are really trying to justify their actions, rather than face the possibility that they might be wrong.

As there is little evidence of effectiveness and growing evidence of harm, should spanking be criminalized and parents brought to the attention of the courts for using this form of discipline? There has already been a lively debate on this subject on our website in response to Durrant and Ensom's article. But most parents, including those who spank, love their children and are trying to be good parents. If the aim is to improve parenting, then calling the police is the wrong approach.
Parents need to be re-educated as to how to discipline their children. Simply discouraging physical punishment is not enough. Without alternatives, parents brought up with spanking may simply substitute shouting or some other form of punishment. How do you teach a whole generation of parents better ways to discipline their children?

Parenting programs have been successful at teaching positive parenting techniques and improving behaviour of children. ${ }^{5}$ Given that a large proportion of the population needs to be taught, education will need to reach beyond just families with overt problems. These programs should be offered widely, perhaps at the same time as antenatal classes and at school entry, times when parents are experiencing change and are receptive to education.

It's not just parents who need to change, though. The law needs to be changed too. Although it is not necessary to make spanking a crime to encourage alternative approaches to parenting, section 43 of the Criminal Code of Canada ${ }^{6}$ sends the wrong message, stating, "... a parent is justified in using force by way of correction ... if the force does not exceed what is reasonable under the circumstances." Law enforcement officers already have discretion to decide when assault is too trivial to merit the full force of the law, and this applies to children as well as adults. But surely any bias should be toward protecting children, who are the most vulnerable. To have a specific code excusing parents is to suggest that assault by a parent is a normal and accepted part of bringing up children. It is not. While section 43 stands, it is a constant excuse for parents to cling to an ineffective method of child discipline when better approaches are available. It is time for Canada to remove this anachronistic excuse for poor parenting from the statute book.

\section{References}

1. Straus MA, Stewart JH. Corporal punishment by American parents: national data on prevalence, chronicity, severity, and duration, in relation to child, and family characteristics. Clin Child Fam Psychol Rev 1999;2:55-70.

2. McCormick KF. Attitudes of primary care physicians toward corporal punishment. JAMA 1992;267:3161-5.

3. MacKenzie MJ, Nicklas E, Brooks-Gunn J, et al. Who spanks infants and toddlers? Evidence from the fragile families and child well-being study. Child Youth Serv Rev 2011;33:1364-73.

4. Durrant J, Ensom R. Physical punishment of children: lessons from 20 years of research. CMAJ 2012;184:1373-6.

5. Barlow J, Smailagic N, Ferriter M, et al. Group-based parent-training programmes for improving emotional and behavioural adjustment in children from birth to three years old. Cochrane Database Syst Rev 2010;(3):CD003680.

6. Barnett L. The "spanking" law: section 43 of the Criminal Code. Ottawa (ON): Parliament of Canada; 2008. Available: www.parl.gc.ca/content/LOP/Research Publications/prb0510-e.htm (accessed 2012 June 26).

Competing interests: See www.cmaj.ca/site/misc/cmaj_staff.xhtml

Affiliation: John Fletcher is Editor-in-Chief, CMAJ

Correspondence to: CMAJ editor, pubs@cmaj.ca

CMAJ 2012. DOI:10.1503/cmaj.121070 